\title{
HUBUNGAN PEMBERIAN ASI EKSKLUSIF DENGAN TUMBUH KEMBANG BAYI USIA 6 - 12 BULAN DI WILAYAH KERJA PUSKESMAS TIPO
}

\author{
Darma Ariany $^{1 *}$, Ade Shafira Putri ${ }^{1}$, Sakina Abdullah ${ }^{1}$ \\ ${ }^{1}$ Program Studi Pendidikan Dokter, Fakultas Kedokteran Universitas Alkhairaat, Jl. Diponegoro No. \\ 39 Palu 94221, Sulawesi Tengah, Indonesia \\ *Corresponding author: Telp: +6285217533043 email: darma_ariany@yahoo.co.id
}

\begin{abstract}
ABSTRAK
Rendahnya pemberian Air Susu Ibu (ASI) Eksklusif dapat menjadi ancaman bagi Tumbuh Kembang Anak (TKA). Tujuan penelitian ini untuk untuk mengetahui hubungan pemberian ASI eksklusif dengan tumbuh kembang bayi usia 6-12 bulan di wilayah kerja Puskesmas Tipo Kota Palu. Metode penelitian yang digunakan cohort retrospective study. Penelitian dilakukan pada tanggal 31 Desember 2018 s/d 04 Februari 2019. Tempat penelitian di Puskesmas Tipo. Besar sampel 116 orang (kelompok kasus 58 dan kelompok kontrol 58). Hasil penelitian yaitu bayi yang diberi ASI eksklusif (70.7\%) lebih banyak mengalami pertumbuhan naik dibandingkan dengan tidak diberikan ASI eksklusif (41.4\%); Bayi yang tidak diberikan ASI eksklusif (58.6\%) lebih banyak mengalami pertumbuhan tidak naik dibandingkan dengan diberikan ASI eksklusif (29.3\%); Perkembangan bayi yang sesuai diberikan ASI eksklusif (86.2\%) dan tidak diberikan ASI eksklusif (68.97\%); Perkembangan bayi yang meragukan pada bayi yang tidak diberikan ASI eksklusif (18.97\%) dan yang diberikan ASI eksklusif (8.6\%); Perkembangan bayi yang menyimpang pada bayi yang tidak diberikan ASI eksklusif (12.06\%) dan yang diberikan ASI eksklusif (5.2\%); Hubungan ASI eksklusif dengan pertumbuhan bayi $(\mathrm{p}=0.001)$ dan hubungan ASI eksklusif dengan perkembangan bayi $(\mathrm{p}=0.084)$. Penelitian ini menunjukkan terdapat hubungan pemberian ASI eksklusif dengan pertumbuhan bayi 6-12 bulan namun tidak terdapat hubungan dengan perkembangan bayi 6-12 bulan.
\end{abstract}

Kata Kunci: ASI Eksklusif, Tumbuh kembang, Puskesmas Tipo

\section{ABSTRACT}

The low supply of exclusive breastfeeding can be a threat to the growth and development of children (TKA). The purpose of this study was to determine the relationship between exclusive breastfeeding and the growth and development of infants aged 6-12 months in the working area of the Tipo Health Center, Palu City. The research method used is a cohort retrospective study. The study was conducted on December 31, 2018 to February 04, 2019. The research site was at the Tipo Health Center. The sample size is 116 people (58 case groups and 58 control groups). The results of the study were that infants who were exclusively breastfed (70.7\%) experienced more growth and growth compared to those who were not exclusively breastfed (41.4\%); Infants who were not exclusively breastfed (58.6\%) experienced more growth that did not increase compared to those who were exclusively breastfed (29.3\%); The development of infants who are suitable for exclusive breastfeeding (86.2\%) and not exclusively breastfed (68.97\%); Doubtful infant development in infants who were not exclusively breastfed (18.97\%) and exclusively breastfed (8.6\%); Deviant infant development in infants who were not exclusively breastfed $(12.06 \%)$ and exclusively breastfed (5.2\%); The relationship between exclusive breastfeeding and infant growth $(p=0.001)$ and the relationship between exclusive breastfeeding and infant development ( $p=0.084)$. This study shows that there is a relationship between exclusive breastfeeding and 
the growth of infants 6-12 months, but there is no relationship with the development of infants 6-12 months.

Keywords: Exclusive breastfeeding, Growth and development, Tipo Health Center

\section{PENDAHULUAN}

Asi eksklusif adalah ASI tanpa tambahan nutrisi kecuali (obat-obatan dan vitamin atau mineral tetes) pada enam bulan pertama bayi baru lahir.,

Rendahnya pemberian ASI dapat menjadi ancaman bagi Tumbuh Kembang Anak (TKA). Padahal, kandungan ASI kaya akan karetonoid dan selenium, sehingga ASI berperan dalam sistem pertahanan tubuh bayi untuk mencegah berbagai penyakit. Setiap tetes ASI juga mengandung mineral dan enzim untuk pencegahan penyakit dan antibodi yang lebih efektif dibandingkan dengan kandungan yang terdapat dalam susu formula, sehingga jika anak mendapatkan ASI bisa dihindarkan dari kematian yang seharusnya tidak perlu. ${ }^{1,2}$

Tumbuh kembang dapat berjalan dengan pemberian ASI eksklusif, Pertumbuhan adalah masalah perubahan dalam ukuran, besar, jumlah atau dimensi tingkat sel, organ maupun individu. Pertumbuhan dapat diukur dengan satuan berat dan panjang badan. ${ }^{3}$

Perkembangan seperti bertambahnya kemampuan, struktur dan fungsi sel menjadi lebih komplek, yang dapat diukur menggunakan skrining perkembangan. Perkembangan sangat dipengaruhi oleh faktor genetik (oleh anak itu sendiri) dan faktor lingkungan. ${ }^{3}$

Pemberian ASI eksklusif sangat berpengaruh dalam proses perkembangan dan pertumbuhan pada anak, karena didalam ASI mengandung banyak zat yang mendukung dalam perkembangan dan kecerdasan motoric. $^{3}$

Di tahun 2014 hanya sekitar 39\% bayi di negara-negara berkembang dan $25 \%$ di Afrika, secara eksklusif mendapatkan ASI selama enam bulan pertama. Selain itu, 6\% bayi di negara-negara berkembang tidak pernah mendapatkan ASI. ${ }^{1,4}$
Di tahun 2010 hasil Riset Kesehatan Dasar (Riskesdas) pemberian ASI di Indonesia baru mencapai 15,3 persen dan pemberian susu formula meningkat hingga tiga kali lipat dari $10,3 \%$ menjadi $32,5 \%$. Menurut Direktur Jenderal Bina Gizi dan Kesehatan Ibu Anak Kementerian Kesehatan, Budiharja, menyatakan bahwa angka ini cukup memprihatinkan. Ia menilai rendahnya kesadaran masyarakat dalam mendorong peningkatan pemberian ASI masih relatif rendah, termasuk kurangnya pengetahuan ibu hamil, keluarga dan masyarakat, akan pentingnya ASI. ${ }^{5}$

Penelitian ini bertujuan Untuk mengetahui hubungan pemberian ASI eksklusif dengan tumbuh kembang bayi usia 6-12 bulan di wilayah kerja puskesmas Tipo Kota Palu.

\section{METODE PENELITIAN}

Desain penelitian yang digunakan adalah analitik observasional dengan pendekatan "cohort retrospective study" dengan menggunakan data primer. Penelitian ini dilakukan pada tanggal tanggal 31 Desember tahun 2018 s/d tanggal 04 Februari tahun 2019. Tempat penelitian yaitu Tempat penelitian di di puskesmas Tipo Palu. Populasi penelitian adalah Populasi penelitian adalah bayi usia 6-12 bulan yang berada di Wilayah Kerja Puskesmas Tipo Palu.

Subyek penelitian adalah bayi usia 612 bulan yang memenuhi kriteria inklusi di Wilayah Kerja Puskesmas Tipo. Cara pengambilan sampel dilakukan dengan cara Random Sampling. Kriteria Inklusi penelitian adalah bayi berumur 6-12 bulan yang diberikan ASI eksklusif di Wilayah Kerja Puskesmas Tipo, Bayi lahir cukup bulan, mempunyai KMS (Kartu Menuju Sehat), Orang tua di Wilayah Kerja Puskesmas Tipo dan Anak mendapat izin ikut penelitian dari 
orang tua tanpa paksaan setelah mendapat penjelasan. Kriteria Eksklusi penelitian adalah lahir pretem/BBLR, bayi lahir gamelli, menderita penyakit kronis, anak menderita keterbelakangan mental dan ibu bayi tidak dapat berkomunikasi.

Pada penelitian ini dilakukan pada Posyandu di Wilayah Kerja Puskesmas Tipo Palu Tahun 2018-2019 terhadap 58 bayi yang diberikan ASI eksklusif (case) dan 58 bayi yang tidak diberikan ASI eksklusif (control). Pengumpulan data dilakukan dengan cara observasi wawancara langsung yang ditulis di dalam kuesioner serta pengukuran berat badan dan panjang badan bayi yang ditulis dalam case report. Data yang diperoleh terdiri dari bayi yang diberikan ASI eksklusif dan tidak diberikan ASI eksklusif, berat badan, panjang badan, KMS (Kartu Menuju Sehat) dan KPSP (Kuesioner Pra Skrining Perkembangan).

Analisis data menggunakan Uji ChiSquare yaitu untuk melihat hubungan pemberian ASI eksklusif dengan tumbuh kembang bayi usia 6-12 bulan di wilayah kerja puskesmas Tipo Kota Palu.

\section{HASIL DAN PEMBAHASAN \\ HASIL \\ Hubungan Pemberian ASI eksklusif dengan Pertumbuhan Bayi Usia 6-12 Bulan di Wilayah Kerja Puskesmas Tipo Palu}

Tabel 1. Hubungan Pemberian ASI eksklusif dengan Pertumbuhan Bayi Usia 6-12 Bulan.

\begin{tabular}{lrllll}
\hline \multirow{2}{*}{ Pemberian ASI } & \multicolumn{2}{c}{ Pertumbuhan } & \multirow{2}{*}{ Total } & \multirow{2}{*}{ p } & \multirow{2}{*}{ RR } \\
\cline { 2 - 4 } & Naik & \multicolumn{1}{c}{ Tidak Naik } & & & \\
\hline ASI Eksklusif & $41(70.7 \%)$ & $17(29.3 \%)$ & $58(100 \%)$ & \multirow{2}{*}{0.001} & \multirow{2}{*}{3.417} \\
Non Eksklusif & $24(41.4 \%)$ & $34(58.6 \%)$ & $58(100 \%)$ & & \\
Total & $65(56.0 \%)$ & $51(44.0 \%)$ & $116(100 \%)$ & & \\
\hline
\end{tabular}

Pada Tabel 1 ditemukan hubungan yang signifikan antara pemberian ASI eksklusif dengan pertumbuhan bayi $(\mathrm{p}=0.001)$. Bayi yang mendapatkan ASI eksklusif lebih banyak dengan pertumbuhan naik dibandingkan dengan yang tidak diberikan ASI eksklusif (70.7\% vs $41.4 \%$ ), pertumbuhan tidak naik lebih banyak pada bayi yang tidak diberikan ASI eksklusif daripada yang mendapatkan ASI eksklusif (58.6\% vs 29.3\%). Dengan nilai Resiko
Relatif 3.417, artinya bayi yang mendapat ASI eksklusif berpeluang mendapatkan pertumbuhan yang naik 3.417 kali lebih besar jika dibandingkan dengan bayi yang tidak diberikan ASI eksklusif.

Hubungan Pemberian ASI eksklusif dengan Perkembangan Bayi Usia 6-12 Bulan di Wilayah Kerja Puskesmas Tipo Palu.

Tabel 2. Hubungan Pemberian ASI eksklusif dengan Perkembangan Bayi Usia 6-12 Bulan.

\begin{tabular}{llllll}
\hline \multirow{2}{*}{ Pemberian ASI } & \multicolumn{3}{c}{ Perkembangan Bayi } & \multirow{2}{*}{ Total } & \multirow{2}{*}{ P } \\
\cline { 2 - 4 } & \multicolumn{1}{c}{ Sesuai } & \multicolumn{1}{c}{ Meragukan } & Menyimpang & & \\
\hline ASI Eksklusif & $50(86.2 \%)$ & $5(8.6 \%)$ & $3(5.2 \%)$ & $58(100 \%)$ & \multirow{2}{*}{$0.084^{*}$} \\
Non Eksklusif & $40(68.97 \%)$ & $11(18.97 \%)$ & $7(12.06 \%)$ & $58(100 \%)$ & \\
Total & $90(77.6 \%)$ & $16(13.8 \%)$ & $10(8.6 \%)$ & $116(100 \%)$ & \\
\hline
\end{tabular}

Pada Tabel 2 ditemukan tidak terdapat hubungan yang signifikan antara pemberian ASI eksklusif dengan perkembangan bayi $(\mathrm{p}=0.084)$. Bayi yang mendapatkan ASI eksklusif lebih banyak dengan perkembangan sesuai dibandingkan dengan yang tidak diberikan ASI eksklusif
$(86.2 \%$ vs $68.97 \%)$, perkembangan meragukan lebih banyak pada bayi yang tidak diberikan ASI eksklusif daripada yang mendapatkan ASI eksklusif $(18.97 \%$ vs 8.6\%), sedangkan perkembangan menyimpang lebih banyak pada bayi yang tidak diberikan ASI eksklusif daripada yang 
mendapatkan ASI eksklusif $(12.06 \%$ vs $5.2 \%)$.

\section{PEMBAHASAN}

1. Hubungan Pemberian ASI eksklusif dengan Pertumbuhan Bayi Usia 6-12 Bulan di Wilayah Kerja Puskesmas Tipo Palu.

Hasil penelitian pertumbuhan bayi menurut KMS (Kartu Menuju Sehat) di dapatkan bayi yang diberikan ASI eksklusif mempunyai pertumbuhan naik lebih banyak daripada bayi yang tidak diberikan ASI eksklusif $(70.7 \%$ vs $41.4 \%$ ), pertumbuhan tidak naik lebih banyak pada bayi yang tidak diberikan ASI eksklusif daripada yang mendapatkan ASI eksklusif $(58.6 \%$ vs 29.3\%). Pada bagian Pearson Chi-Square terlihat nilai $p$ value sebesar 0.001. Karena nilai $p$ value $0.001 \quad(\mathrm{p}<0.05)$, maka dapat disimpulkan bahwa terdapat hubungan yang signifikan antara pemberian ASI eksklusif dengan pertumbuhan bayi. Hal ini disebabkan karena pemberian ASI eksklusif yang diberikan ibu sudah memenuhi kebutuhan asupan gizi bayi sehingga berat badan bayi menjadi optimal.

Hasil penelitian ini sejalan dengan penelitian (Zulyana, 2016) bahwa terdapat hubungan pemberian ASI eksklusif dengan pertumbuhan berdasarkan indeks pertumbuhan $\mathrm{PB} / \mathrm{U}$ dengan hasil uji statistic chi-square diperoleh nilai $p$ value $=0.029$ $(\mathrm{p}<0.05)$. Hasil ini menunjukkan bahwa terdapat hubungan antara pemberian ASI eksklusif dengan pertumbuhan bayi menurut indeks pertumbuhan $\mathrm{PB} / \mathrm{U}^{6}$

2. Hubungan Pemberian ASI eksklusif dengan Perkembangan Bayi Usia 6-12 Bulan di Wilayah Kerja Puskesmas Tipo Palu.

Hasil penelitian perkembangan menurut KPSP (Kuesioner Pra Skrining Perkembangan) didapatkan Perkembangan bayi yang sesuai lebih banyak ditemukan pada bayi yang mendapatkan ASI eksklusif dibandingkan dengan yang tidak diberikan ASI eksklusif $(86.2 \%$ vs $68.97 \%)$, perkembangan meragukan lebih banyak pada bayi yang tidak diberikan ASI eksklusif daripada yang mendapatkan ASI eksklusif (18.97\% vs $8.6 \%$ ), sedangkan perkembangan menyimpang lebih banyak pada bayi yang tidak diberikan ASI eksklusif daripada yang mendapatkan ASI eksklusif (12.06\% vs 5.2\%). Pada bagian Pearson Chi-Square terlihat nilai $p$ value sebesar 0.084 . Karena nilai $p$ value $0.084(\mathrm{p}>0.05)$, maka dapat disimpulkan bahwa tidak terdapat hubungan yang signifikan antara pemberian ASI eksklusif dengan perkembangan bayi. Hal ini mungkin disebabkan oleh adanya pengaruh lain seperti kualitas dan kuantitas ASI yang belum tercapai dengan baik sehingga mempengaruhi pertumbuhan otak bayi dan berdampak pada terlambatnya perkembangan bayi. Selain itu faktor lingkungan, stimulasi, dan sosial ekonomi juga mempengaruhi proses perkembangan.

Hasil penelitian ini sejalan dengan penelitian (Fitri et all, 2014) bahwa tidak terdapat hubungan pemberian ASI eksklusif dengan perkembangan bayi umur 6 bulan dengan hasil uji statistik Chi-Square diperoleh nilai $p$ value $=0,062(\mathrm{p}>0.05)$. Berdasarkan hasil tersebut dapat disimpulkan bahwa hubungan pemberian ASI dengan perkembangan bayi tidak signifikan. ${ }^{7}$

\section{KESIMPULAN}

Berdasarkan hasil analisis pada penelitian tersebut disimpulkan bahwa dari 58 bayi yang diberikan ASI eksklusif dan 58 bayi yang tidak diberikan ASI eksklusif di Wilayah Kerja Puskesmas Tipo Palu tentang ASI eksklusif yang berhubungan dengan pertumbuhan dan perkembangan bayi, kesimpulannya sebagai berikut:

1. Terdapat hubungan yang signifikan antara pemberian ASI eksklusif dengan pertumbuhan bayi usia 6-12 bulan.

2. Tidak terdapat hubungan yang signifikan antara pemberian ASI eksklusif dengan perkembangan bayi usia 6-12 bulan. 


\section{DAFTAR PUSTAKA}

1. Kramer MS, Kakuma R. Optimal duration of exclusive breastfeeding. 2012 .

2. Situasi dan Analisis ASI Eksklusif. INFODATIN; KEMENKES 2014.

3. Soetjiningsih. Tumbuh Kembang anak. Jakarta: Penerbit Buku Kedokteran EGC; 2012.

4. Early Initiation of Complementary Feeding and Associated Factors among 6 Months to 2 Years Young Children, in Kamba Woreda, South West Ethiopia: A Community -Based Cross - Sectional Study: Eskezyiaw Agedew, et all; 2014.
5. Dwiharso. Christoforus Nata. Tingkat Pemberian ASI Eksklusif Di Indonesia. 2010.

6. Zulyana. Hubungan pemberian ASI Eksklusif dengan tumbuh kembang bayi usia 6-12 bulan di wilayah kerja puskesmas anak air padang tahun 2016. Diploma thesis, Universitas Andalas. 2016

7. Fitri DI, Chundrayetti E, Semiarty R. Hubungan Pemberian ASI dengan Tumbuh Kembang Bayi Umur 6 Bulan di Puskesmas Nanggalo. Jurnal Kesehatan Andalas. 2014;3(2). doi:10.25077/JKA.V3I2.51 